\title{
NÁSTROJE PŘREINVESTIČNÍ FÁZE PROJEKTU A JEJICH VÝZNAM V INVESTIČNÍM ROZHODOVÁNÍ NA ÚROVNI OBCÍ A MĽST
}

\section{TOOLS PRE-INVESTMENT PHASE PROJECT AND THEIR IMPORTANCE IN THE INVESTMENT DECISION-MAKING AT MUNICIPALITY LEVEL}

\begin{abstract}
Anotace
Úlohou municipálni samosprávy je rozhodnout o efektivni alokaci veřejných prostředků s co největším celospolečenským př́nosem. Rozhodováni z pohledu municipálního managementu o realizaci či nerealizaci veřejného projektu s sebou nese vysokou odpovédnost. Dopady rozhodnutí se promitaji na subjekty regionálního prostředí. Nástrojem pro řešeni těchto otázek jsou technicko-ekonomické studie. Dokument analyzuje tyto nástroje z hlediska jejich výstupi̊, podstaty, výsledků a významu pro rozhodování. Nejvíce podporovaným nástrojem jsou studie proveditelnosti. Svi̊j význam ovšem maji také dalši technicko-ekonomické studie, které maji svůj dopad v procesu ř́zení regionálního rozvoje.
\end{abstract}

\section{Kličová slova}

municipální management, veřejný projekt, předinvestični proces, rozhodováni, studie proveditelnosti, analýza nákladì a prínosì

\section{Annotation}

The role of municipal government is to decide on the efficient allocation of public resources with the greatest societal benefit. Decision-making from the perspective of the municipality management of realization or non realization of the public project carries a high responsibility. Implications of decisions are reflected in the regional environment. Tool for addressing those issues are technical and economic studies. The document analyzes these tools in terms of their outputs, deliverables, results and relevance for decision-making. Most tools are supported by a feasibility study. Its importance, however, also have other techno-economic studies, which have an impact in the process of regional development.

\section{Key words}

municipality management, public project, pre-investment process, feasibility study, cost benefit analysis

JEL classification: $R 58$, M19

\section{Úvod}

Veřejný sektor při rozhodování umístění investičních prostředků sleduje - kritérium efektivnosti a účinnosti. Základním východiskem je skutečnost, že každá obec, kraj má velké množství možností, kde a jak alokovat finanční prostředky, ale omezené množství zdrojů - finančních i nefinančních. Úlohou samosprávy je tedy rozhodnout o efektivní alokaci veřejných prostředků s co největším 
celospolečenským dopadem. Tyto otázky pomáhá řešit aparát technicko-ekonomických studií, který je součástí předinvestiční fáze životního cyklu. Není možné podcenit formu, kvalitu zpracování a to i přesto, že se jedná o činnosti finančně odborně i časově nákladné.

Cílem je provést analýzu zavedených instrumentů předinvestičního procesu pro oblast municipalit a definovat jejich specifika a význam z hlediska efektivního a účinného rozhodování. Zavedené instrumenty jsou představeny z úrovně výstupů, výsledků a dopadů na správné řízení. Postupy pro správné rozhodnutí se mohou lišit podle náročnosti, rozsahu a zaměření investice.

V ekonomické teorii bývá pojem investice charakterizován jako odložená spotřeba. Tento pojem můžeme chápat zásadně dvojím způsobem: investiční činnost je ve veřejném i soukromém sektoru zaměřena především na obnovu a rozšíření hmotného a nehmotného investičního majetku, nazývaného jako dlouhodobý majetek. Investování chápeme jako pořízení takového aktiva, které v budoucnosti přinese svému vlastníkovi určitý ekonomický prospěch nebo v podobě jiného efektu typicky to platí pro investice ve veřejném sektoru, kdy budoucí prospěch může spočívat v poskytnutí služby pro občana (např. zavedení datových schránek, zajištění bezpečnosti občana, např. realizací protipovodňových opatření, vybudování kamerového systému či zlepšení kvality života občana modernizací školy, uměleckého zařízení apod.). Pro investiční činnost je typická její dlouhodobost, je nezbytné uvažovat $\mathrm{s}$ faktorem času, s rizikem změn po dobu plánování, príípravy i realizace daného investičního projektu. Pro investiční plánování je velmi důležitá komplexní znalost vnitřních i vnějších podmínek, za kterých se investice uskutečňuje, a ve kterých bude působit.

\section{Př́stupy k investičnímu rozhodování a uplatňované nástroje}

Kritériem pro rozhodnutí o realizaci veřejného projektu je jejich efektivita a účinnost tzn. dosažení žádoucího celospolečenského efektu. Pro rozhodování o veřejných investicích je charakteristické, že jde o dlouhodobé rozhodování, při kterém je nezbytné vzít v úvahu: faktor času, riziko vyplývající z jedinečnosti projektu a specifika rozhodování ve veřejném zájmu. Veřejný projekt lze chápat jako „systémový návrh alokace veřejných zdrojů, který má (zpravidla) charakter investiční akce“. Problematika týkající se veřejných projektů je nedílnou součástí veřejných financí potažmo veřejných výdajů obecně. Rozdíl oproti investicím realizovaným v komerční sfére je tedy zásadní. Zajímá nás i užitek resp. náklad jiného, nežli investujícího subjektu.

Proces př́ípravy a realizace investiční akce od jeho začátku až po jeho ukončení, můžeme rozdělit do čtyř základních fází projektu, stejně jako u podnikatelských projektů (Fotr, Souček, 2005). Jednotlivé fáze životního cyklu investice jsou: před-investiční (iniciační, př́pravná) fáze, investiční fáze, provozní fáze, likvidační fáze. Podstatou předinvestiční fáze je identifikace př́iležitostí, poté se provede předběžný výběr projektů, příprava projektu včetně jeho variant a následně se provede vyhodnocení a rozhodnutí o realizaci či zamítnutí. Uznávanými instrumenty jsou předinvestiční studie, které jsou velmi účinné pro efektivní ř́zení a rozhodování v otázkách investičních výdajů. Nejvíce uznávaným nástrojem této fáze je studie proveditelnosti.

Cílem předinvestičních studií je především snížit rizika spojená s realizací projektu. Tyto studie jsou nástrojem dosažení cílů stanovených v ekonomických a rozvojových plánech. Předinvestiční studie sledují systematický prrístup $\mathrm{k}$ identifikaci, přípravě, podpoře a vyhodnocení projektu. Zaměřují se na př́pravu projektu a identifikaci strategických cílů a alternativ projektu (Frohlich, 1994). Předinvestiční studie nastiňují organizační rámec, včetně manažerských a technických funkcí, navrhují velikost a skladbu projektového týmu a připravují organizační plány, schémata a časové harmonogramy. (Frohlich, 1994). Na konci před-investiční fáze se rozhoduje o dalším osudu projektu, zda jej realizovat nebo od něj upustit.

Mezinárodní organizace OSN pro hospodářský rozvoj UNIDO - United Nation Industrial Development Organization, která se dlouhodobě snaží o rozvoj podnikání malých a středních podniků, vyvinula, připravila a prezentovala světové veřejnosti koncept pro definování projektových potřeb, jehož součástí je plánování, analýza a hodnocení investičních akcí. Tento koncept UNIDO přijaly organizace podnikatelského sektoru a organizace veřejného sektoru, kterých se oblast prŕpravy a 
realizace investičních projektů týká. Hlavními činnostmi předinvestiční fáze je zpracování podkladů k objektivizaci rozhodování o volbě a realizaci vybrané alternativy projektu.

Účelem této předinvestiční fáze dle UNIDO je:

- identifikace př́ležitostí;

- analýza alternativ projektu z hlediska jejich proveditelnosti a rizik;

- předběžný výběr vhodné alternativy;

- specifikace zadání a rozpracování vybrané alternativy;

- odhad př́nosů a výdajů projektu (očekávaná potřeba a tvorba zdrojů);

- rozhodnutí o realizaci projektu.

Další přístup pro předinvestiční fázi nabízí také Ministerstvo pro místní rozvoj ve své metodické př́ručce pro tvorbu studie proveditelnosti (Sieber, 2004). Dle metodické prŕručky Ministerstva pro místní rozvoj je doporučeno, v rámci př́ípravy investičních projektů, využít Studie příležitostí, která pokládá základ předinvestiční fáze, kde je definována co největší řada investičních př́iležitostí, o nichž lze v této etapě uvažovat jako o potenciálně ekonomicky výnosných. Předběžná studie proveditelnosti je jakýmsi mezistupněm mezi zásadním rozhodovacím dokumentem studí proveditelnosti a zmíněnou studií př́ležitostí. Předběžná studie proveditelnosti se strukturou uvedených informací de facto neliší od studie proveditelnosti. Rozdíl spočívá v podrobnosti a přesnosti zpracování. Hodnotící zpráva je název pro dokument, který hodnotí projekt na základě různých finančních ukazatelů a zároveň do hodnocení často zahrnuje posouzení finančního zdraví investora (realizátora projektu). Analýza nákladů a př́nosů, pokládá základní otázku: „Co komu realizace investičního projektu přináší a co komu bere?"

Němec (2006) se zmiňuje o dvou základních nástrojích předinvestičního procesu zaměřeného na př́pravu předinvestičních projektů - úvodní studie proveditelnosti a úplná studie proveditelnosti. Fiala (2004) ve své knize předinvestiční fázi nazývá jako fázi koncepční, která je týmovou analýzou problému s vygenerováním možných řešení. Tento proces dle Fialy vyústí ve studii proveditelnosti, která navrhne zásadní postup řešení, identifikuje požadavky na zdroje pro dosažení cíle projektu.

Na základě výše zmíněného průzkumu jednotlivých metodologických př́stupů lze tedy říct, že předinvestiční studie jsou uznávanými instrumenty pro efektivní ř́zení a zejména př́pravu investice. Neexistuje však jednotná metodika pro uplatňování těchto nástrojů na úrovni obce či města. Poměrně uznávaným nástrojem municipalit této fáze je studie proveditelnosti, ostatní nástroje jsou využívány okrajově. Mezi základní technicko-ekonomické studie využívané ve veřejném sektoru ve fázi předinvestiční přípravy projektů patří:

- Myšlenka a projektová fiše (Project charter),

- Studie př́ležitostí (Opportunity study - OS),

- Podpůrné studie (Support studies - SS),

- Předběžná studie proveditelnosti (Pre-feasibility study- PRE FS),

- Studie proveditelnosti (Feasibility study - FS),

- Analýza nákladů a prínosů v prŕ́padě veřejných investic (Cost benefit analysis - CBA),

- Hodnotící zpráva projektu (Appraisal report - AR).

Cílem předinvestičních studií je především snížit rizika spojená s realizací projektu. Tyto studie jsou nástrojem dosažení cílů stanovených v ekonomických a rozvojových plánech. Předinvestiční studie sledují systematický prŕstup $\mathrm{k}$ identifikaci, př́ípravě, podpoře a vyhodnocení projektu. Zaměřují se na př́pravu projektu a identifikaci strategických cílů a alternativ projektu. (Frohlich, 1994). Rozhodnutí o realizaci investice je závěrečnou částí předinvestiční fáze projektu. $V$ tomto stádiu je třeba rozhodnout o možnosti príjetí projektu bez dalších úprav nebo projektový záměr - studii proveditelnosti v některých částech upravit či projekt zamítnout. Tím před-investiční fáze končí. Pokud je navrhovaný projekt schválen, přechází do další investiční fáze.

Hlavní argumenty pro vypracování předinvestičních studií jsou:

- optimální alokace zdrojů 
- redukce chybovosti

- podpora projektu s informacemi pro potenciální investory

- stanovení veřejných dopadů a celospolečenských prínosů

\section{Studie př́ležitostí (Opportunity study - OS)}

Smyslem studie př́ležitostí je identifikovat a podporovat projekt v určitém sektoru. Studie definuje existující př́ležitosti a podmínky pro úspěch projektu, poskytuje kompletní informace o zdrojích, místních podmínkách, podnikatelském prostředí a dalších faktorech ovlivňujících realizaci projektu. Oblastní studie prŕležitostí řeší celkový rozvoj oblasti bez zdůrazňování jednotlivých sektorů. Mohou se týkat jednoho (spíše homogenního) regionu, který je zřetelně ohraničený nebo více regionů s podobnými socio-ekonomickými a kulturními rysy. Rozdíly vycházejí z velikosti vybraných oblastí - čím menší oblast, tím více specifické a limitované jsou investiční př́ležitosti a projekty. Oblastní studie tedy může řešit rozvoj území konkrétního města, kraje či lokality (např́klad horské oblasti, mikroregionu, průmyslové lokality, strukturálně postiženého území apod.) bez zaměření na předem definované oblasti.

Sektorové studie se obecně vztahují k určitému sektoru nebo skupině sektorů. V tomto kontextu se studie koncentruje na trh, lidské zdroje a technologie a také na možnosti jejich přenosu do úspěšných projektů. Analogie odvozené z meziregionálních nebo mezinárodních sektorových srovnání jsou přizpůsobeny sektorovým a regionálním podmínkám (Fotr, Souček, 2005). Př́kladem lze uvést např́klad studii, která bude zaměřená na rozvoj cestovního ruchu v dané územní jednotce či lokalitě se společnými rysy. Snižují náklady na př́pravu studie proveditelnosti, protože informace, data, jsou již shromážděna a analyzována na úrovni studie př́ležitostí, mohou být dále sdílena více potenciálními investory a mnoha jednotlivými projekty. Jedna studie př́ležitostí může sloužit pro více studií proveditelnosti.

\section{Výsledky studie a dopad na rozhodování samosprávy}

Studie př́ležitostí vyhodnocují význam lokality, odvětví a posuzují dopady rozhodnutí. Vymezují reálné možnosti investování před tím, než jsou některé $\mathrm{z}$ nich zvoleny $\mathrm{k}$ podrobnějšímu a tedy nákladnějšímu zpracování například v podobě pre-feasibility či feasibility study. Výstupem je utříděný soubor potenciálních investic, který se stává součástí zásobníku projektů obce či města. Poskytují základní informace o faktorech ovlivňujících provedení projektů bez ohledu na to, zda jde o faktory interní či externí. Poskytují základní klíčové informace a také specifická data pro každou vybranou pŕíležitost $\mathrm{s}$ důrazem na typické faktory, vstupy a charakteristiku projektu, včetně kritických proměnných, rizika, konkurenceschopnosti, ziskovosti a další podmínky úspěšnosti projektů. Získané informace vhodně doplňují a upřesňují analytickou část strategie rozvoje území.

\section{Projektová fiše}

Projektová fiše (Project Charter - dále PC) je krátký dokument v ideálním př́padě jedna strana, který přesně stanoví, co je třeba udělat $\mathrm{v}$ rámci projektu, proč je to třeba udělat, a jaké jsou požadavky zadavatele pro jeho plnou spokojenost. Hlavním cílem je zajistit souhlas vedení a získat zdroje potřebné k vypracování podrobného plánu projektu. Ten bude dále přezkoumán manažery, kteří mají odpovědnost za stanovení priorit a rozhodování o tom, jaké projekty podporovat. (Wysocki, a další, 2003). Po schválení se stane základem pro budoucí plánování a realizaci projektu. Stává se referenčním dokumentem pro otázky nebo spory týkající se rozsahu projektu a plnění jeho účelu.

\section{Výsledky studie a dopad na rozhodování samosprávy}

Projektová fiše vymezuje problém či příležitost, kterou projekt řeší. Stanovují cíl a účel projektu - to, co máte $\mathrm{v}$ úmyslu řešit. Důraz je kladen na vymezení problému či příležitosti, dále objasňuje přesné hranice projektu a jeho výstupy. Identifikuje kritéria úspěšnosti projektu a poskytujeme prohlášení o 
dosažené obchodní hodnotě projektu. Tvoří základ informační báze projektu a vstupuje do zásobníků projektu obce či města.

\section{Předběžná technicko - ekonomická studie (Pre-feasibility study - Pre FS)}

Představuje určitý mezistupeň mezi stručnými studiemi př́ležitostí a podrobnými technicko ekonomickými studiemi. Cílem zpracování předběžné Pre FS studie je určit, zda byly vyšetřeny a posouzeny všechny možné varianty projektu a zda povaha a náplň projektu opravňuje ke zpracování podrobné studie proveditelnosti. Pre FS zkoumá atraktivnost pro investory a podnikatelskou př́ležitost pro investory. V neposlední řadě zkoumá, zda stav životního prostředí v předpokládané lokalitě realizace odpovídá standardům. Všechna často variantní řešení a jejich ekonomické dopady jsou již na určité hrubé úrovni podrobnosti kvantifikovány do podoby finančních toků. U malých a jednoduchých projektů jsou dostatečným podkladem pro rozhodování, zda pokračovat vinvestiční fázi. U komplexních a speciálních projektů je však nezbytné pro rozhodnutí, zda pokračovat $\mathrm{v}$ př́pravě komplexním zpracováním FS nebo návrh projektu zamítnout. (Němec, 2006). Pro oblast veřejné sféry je možné konstatovat poměrně velkou absenci při zpracování Pre FS.

\section{Výsledky studie a dopad na rozhodování samosprávy}

Předběžná, neboli úvodní studie proveditelnosti, je vhodná pro získání základní informace $\mathrm{k}$ projektovému řešení a rámcovému odhadu zdrojů, na základě kterého se rozhodovací orgány mohou rozhodnout o príípravě podrobnějšího plánu. Specifikem Pre FS často bývá, že je zpracována variantě, tedy navrhuje dvě a více projektových řešení. V tomto prrípadě je pak součástí studie také kvalifikované zhodnocení variant. Vybraná varianta se promítne do návrhové části strategie rozvoje území. Na základě této studie by se měl investor rozhodnout, zda uvolní další finanční a jiné zdroje na dopracování detailní studie proveditelnosti, či přípravné práce na projektu zastaví.

\section{Studie proveditelnosti - Feasibility study (FS)}

Smyslem zpracování FS je poskytnout veškeré podklady potřebné pro investiční rozhodnutí. Základním cílem studie proveditelnosti je celkové vyhodnocení projektového záměru rozpracováním ekonomických, finančních, manažerských a marketingových aspektů projektu. Studie proveditelnosti je tedy orientována spíše na komplexní popis všech realizačních stránek investice včetně jejich zohlednění ve finančních tocích a na trhu. Zahájit proces realizace studie proveditelnosti je doporučen v prŕípadě, že instituce má možnost zajištění zdrojů pro př́ípadnou realizaci projektu a projekt zapadá do strategie a je podporován rozhodovací většinou. V prostředí veřejné sféry je s prŕpravou studie proveditelnosti poměrně velká zkušenost, jelikož zpracování této studie je podmínkou při podávání žádostí o financování projektů z EU. Rovněž bankovní domy si kladou podmínky zpracování FS v príípadě žádostí o úvěr. Hlavním rozdíl mezi Pre FS a FS spočívá v úrovni rozpracovanosti jednotlivých oblastí, ve využití dat a v hloubce analýz.

\section{Výsledky studie a dopad na rozhodování samosprávy}

Studie podrobně definuje projekt včetně cílů, základních technických, technologických a marketingových hledisek a finanční ch ekonomických hledisek. Rozhoduje o proveditelnosti či neproveditelnosti projektu a př́padně posouvá investici do její realizační fáze. Výsledkem studie proveditelnosti je definování realizovatelnosti či nerealizovatelnosti projektu. V př́padě rozhodnutí o realizovatelnosti projektu následuje zpracování podrobné technické projektové dokumentace studie nebo rozhodnutí o zastavení dalších prací. Ve druhém př́ípadě se ovšem jedná o tzv. sunk cost (utopené náklady). Investice je posouzena jako vhodná se stává součástí akčního plánu, rozpočtových výhledů a plánu pro zajištění zdrojů apod. 


\section{Analýza nákladů a př́nosů - Cost benefit analysis (CBA)}

Smyslem studie je vyčíslit nejen finanční náklady na realizaci projektu a výnosy, které z něj bezprostředně plynou zrrizovateli, ale současně i finančně zhodnotit všechny další socioekonomické a environmetální prínosy či újmy. CBA tak umožňuje hodnotit výhodnost investic i u projektů, které výsledně nepřinášejí zisk (Reilly, 2007). CBA je zaměřena na zkoumání výsledných efektů a dopadů projektu na veškeré subjekty. Zabývá se ekonomickým hodnocením projektu a zjištováním jeho smysluplnosti. Je vhodná zejména pro oblast veřejných projektů, kde nás zajímají dopady projektu na širší spektrum zúčastněných beneficienti̊. $V$ běžné praxi se CBA využívá za předpokladů, že je povinnou náležitostí př́ípravy žádosti o dotaci. U projektů, kde tato povinnost není, je studie CBA zcela absentována, zejména z důvodu jejich finanční a časové náročnosti. CBA není jedinou metodou pro hodnocení celospolečenských dopadů, je to ovšem metoda, která byla podporována z úrovně Evropské Unie, a proto se její používání rozšíríilo.

\section{Výsledky studie a dopad na rozhodování samosprávy}

Výsledkem studie je identifikace a kvantifikace společenské dopadů na konkrétní kategorie beneficientů. Tyto př́nosy či újmy jsou následně převedeny na hotovostní toky. Postup v metodě CBA je také nazýván ekonomickým hodnocením projektu. Východiskem pro identifikaci celospolečenských dopadů je analýza všech zainteresovaných skupin, resp. beneficientů, která ukazuje na očekávanou změnu chování subjektů po dokončení daného projektu. Přínosy (benefity) jsou veškeré pozitivní dopady na zkoumané subjekty, či jejich skupinu. Jedná se o kladné efekty plynoucí z investice. Předmětem zkoumání jsou tzv. kladné externality, tedy úspory či výnosy vznikající při realizaci projektu třetí straně, která stojí mimo tuto transakci. Naopak náklady, přeneseně také újmy (costs), znamenají negativní dopady na zkoumaný subjekt(y), či jejich skupinu. Jedná se o záporné efekty plynoucí z investice. (Sieber, 2004).

Analýza CBA nám umožňuje rozhodnutí o přijatelnosti investice z pohledu celospolečenských efektů, díky kvantifikace socioekonomických a environmentální př́nosů umožňuje vhodným způsobem nastavit monitorovací indikátory celospolečenského posunu v rámci realizované investice.

\section{Obr. 1: Základní členění nákladi̊ a př́nosi̊}

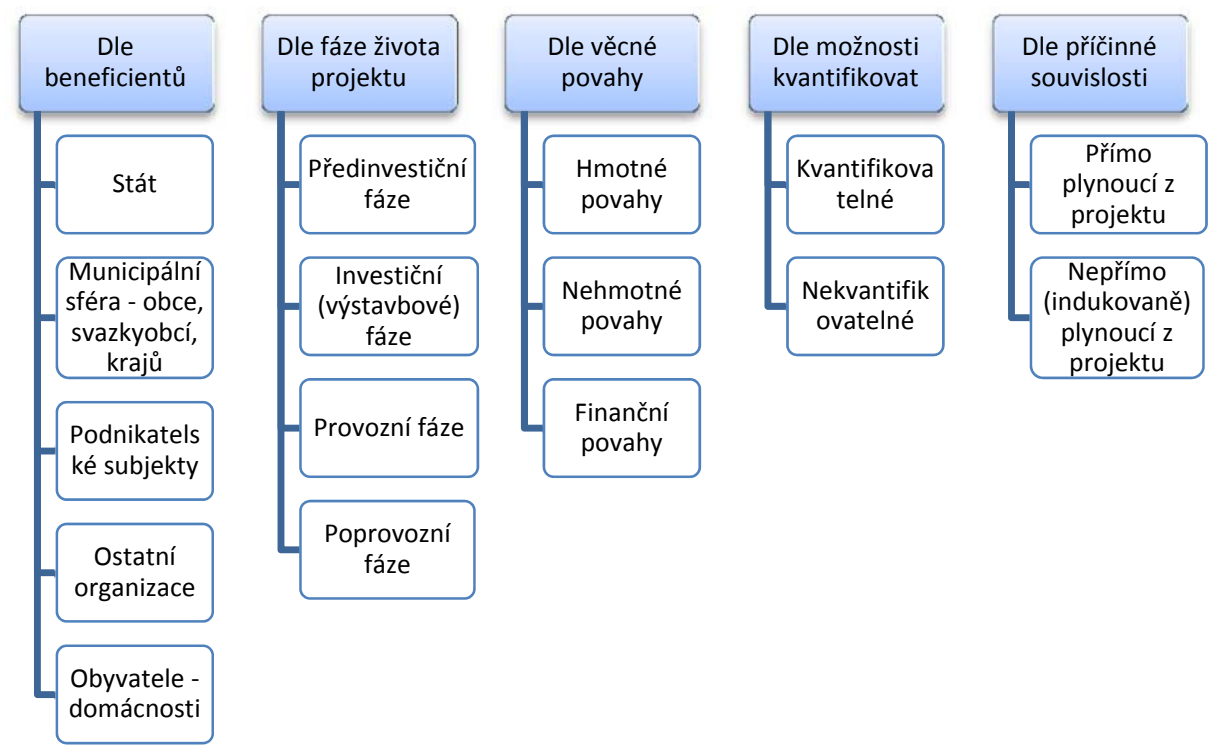

Zdroj: vlastní zpracování (Václavková, 2010) 


\section{Podpůrné analýzy, studie, průzkumy a rozbory}

Podpůrné oborové studie, analýzy, průzkumy a rozbory (dále je podpůrné studie) jsou běžnou praxí $\mathrm{v}$ prostředí veřejných i komerčních projekti̊. Tyto studie jsou charakteristické svou vysokou odbornou specializací. Studie výhradně zajišt'ují specializované organizace, které se danou problematikou zabývají. Struktura těchto studií není pevně daná a vždy odpovídá konkrétním požadavkům zadavatele a obecným zvyklostem zpracovatele. Jedná se o technické studie, analýzy, rozbory, průzkumy a ostatní specifické studie dle požadavků zadavatele.

\section{Výsledky studie a dopad na rozhodování samosprávy}

Technicky řeší specifické otázky investice - např. studie ozvučení, archeologický průzkum, kde zpravidla doplňují či technicky upřesňují studii proveditelnosti. Zjišt’ují dopady a vlivy projektu na území, objekt, životní prostředí, odvětví, zainteresované skupiny, cílovou skupinu apod. Slouží jako podpůrný nástroj pro výběr alternativy - např. metodika hodnocení, studie zdrojů apod. Řeší další specifické otázky dle požadavků zadavatele.

\section{Hodnotící zpráva - Appraisal report (AR)}

Součástí předinvestičního procesu bývá také zpracování hodnotící zprávy, která je základním podkladem pro hodnocení projektu investičními a finančními institucemi, které by se mohly podílet na jeho financování. Tyto instituce k tvorbě takového dokumentu využívají vlastní postupy a procedury. Často se kromě projektu hodnotí též finanční zdraví firmy či organizace, která jej hodlá realizovat. Výsledky posouzení včetně hodnocení projektu jsou shrnuty do písemné hodnotící zprávy (Appraisal report), která se odlišuje podle oboru a zpracovatele. Metodika je obvykle definována jejím uživatelem či zpracovatelem, a proto se může subjekt od subjektu lišit.

Hodnotící zpráva hodnotí projekt na základě různých finančních ukazatelů včetně finančního zdraví investora či realizátora projektu. Studie proveditelnosti, finanční analýza a finanční plán investora či CBA je základním kamenem zpracování hodnotící zprávy. Na základě hodnotící zprávy obvykle padne rozhodnutí o investici, poskytnutí úvěru apod. Je tedy vhodná pro instituce poskytující finanční či jiné zdroje pro realizaci projektu, kterým slouží jako hodnotící nástroj. Právě bankovní domy či fondy rizikového kapitálu využívají speciálně připraveného dokumentu při rozhodování o své finanční investici do projektu. Možná osnova dokumentu se skládá obvykle z těchto sekcí: celkové shrnutí projektu; definice obchodního př́ípadu; projektového plánu; vlastní hodnocení projektu a kalkulace hodnotících kritérií.

\section{Specifika a význam pro rozhodování}

Hodnotící zpráva je zpravidla formulář, který hodnotí zjištěné skutečnosti z předchozích studií. Nejedná se o zpracování informací, ale pouze o syntézu zjištěných skutečností. Nejpodstatnější částí je kapitola, kde probíhá vlastní hodnocení projektu. Na základě přiděleného skóre v jednotlivých sekcích se určuje, zda projekt bude úspěšný, či nikoliv.

\section{Zhodnocení významu nástrojů}

Následující graf definuje výstupy a výsledky zmiňovaných technicko-ekonomických studií. Znázorněn je př́nos v procesu investičního rozhodování a jejich dopad na ostatní dokumenty využívané v procesu řízení regionálního rozvoje na úrovni obce. 
Obr. 2: Výstupy a výsledky technicko-ekonomických studií

\begin{tabular}{|c|c|c|c|}
\hline Nástroj & Výstup & Výsledek & Dopad \\
\hline Studie příležitostí & $\begin{array}{l}\text { Analýza př́ležitostí pro } \\
\text { konkrétní území či } \\
\text { odvětví. }\end{array}$ & $\begin{array}{l}\text { Identifikace } \begin{array}{r}\text { př́ležitostí, } \\
\text { specifikace } \\
\text { možnojektových }\end{array} \\
\end{array}$ & $\begin{array}{lr}\text { Zásobník } & \text { projektů } \\
\text { Strategie rozvoje } & \text { ró } \\
\text { území - analytická část }\end{array}$ \\
\hline Projektová fiše & $\begin{array}{l}\text { Rámcová specifikace } \\
\text { projektu. }\end{array}$ & 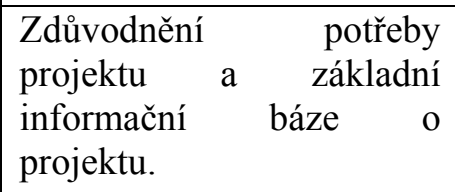 & Zásobník \\
\hline $\begin{array}{l}\text { Předběžná studie } \\
\text { proveditelnosti }\end{array}$ & $\begin{array}{l}\text { Rámcová, zjednodušená } \\
\text { strategie (variantního) } \\
\text { řešení projektu a jeho } \\
\text { rizik z pohledu } \\
\text { marketingového, } \\
\text { technické, projektového } \\
\text { a finančního rrešení } \\
\text { projektu. }\end{array}$ & $\begin{array}{lr}\text { Předběžné } & \text { (rámcové) } \\
\text { rozhodnutí } & \mathrm{o} \\
\text { proveditelnosti } & \text { projektu } \\
\text { otázkách: } & \\
\text { atraktivity } & \text { projektu pro trh } \\
\text { a } & \text { zákazníka. } \\
\text { finanční } & \text { efektivnosti } \\
\text { projektu. } & \\
\text { technického } & \text { řešení } \\
\text { projektu } & \\
\text { a projektového řešení. }\end{array}$ & $\begin{array}{l}\text { Strategie rozvoje } \\
\text { území - návrhová část } \\
\text { Akční plán } \\
\text { Plán investic } \\
\text { Rozpočtový výhled } \\
\text { Rozpočet obce }\end{array}$ \\
\hline $\begin{array}{l}\text { Studie } \\
\text { proveditelnosti }\end{array}$ & $\begin{array}{l}\text { Strategie (variantního) } \\
\text { řešení projektu a jeho } \\
\text { rizik z pohledu } \\
\text { marketingového, } \\
\text { technické, projektového } \\
\text { a finančního řešení } \\
\text { projektu. }\end{array}$ & 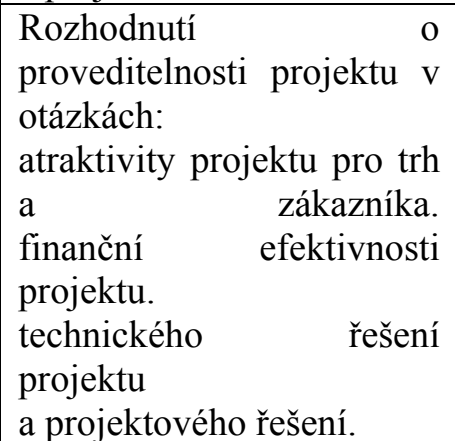 & $\begin{array}{lr}\text { Strategie } & \text { rozvoje } \\
\text { území- návrhová část } \\
\text { Akční } \\
\text { Plán rán } \\
\text { Rozpočtový výhled }\end{array}$ \\
\hline $\begin{array}{l}\text { Ekonomická } \\
\text { analýza }\end{array}$ & $\begin{array}{l}\text { Ekonomické } \\
\text { zhodnocení projektu na } \\
\text { základě aparátu finanční } \\
\text { analýzy. }\end{array}$ & $\begin{array}{l}\text { Stanovení } \\
\text { celospolečenských přínosů } \\
\text { a nákladů projektu pro } \\
\text { jednotlivér kategorie } \\
\begin{array}{l}\text { zainteresovaných skupin } \\
\text { beneficientů. }\end{array}\end{array}$ & $\begin{array}{l}\text { Strategie projektů - } \\
\text { návrhová } \\
\text { monitorovacíst, } \\
\text { indikátory. } \\
\begin{array}{l}\text { Soupis prioritních } \\
\text { projektů }\end{array}\end{array}$ \\
\hline Podpůrné studie & $\begin{array}{l}\begin{array}{l}\text { Technická } \\
\text { specifikace }\end{array} \text { (analýzý, } \\
\text { rozbor, } \\
\text { konkrétního problému. }\end{array}$ & $\begin{array}{l}\text { Řešení odborných a } \\
\text { specifických otázek } \\
\text { vztahující se k projektu. }\end{array}$ & $\begin{array}{l}\text { Projektová fiše } \\
\text { Studie proveditelnosti } \\
\text { Ekonomická analýza }\end{array}$ \\
\hline
\end{tabular}

\section{Závěr}

Rozhodování z pohledu veřejného subjektu o realizaci či nerealizaci projektu s sebou nese vysokou odpovědnost, jelikož účinky se promítají na subjekty regionálního prostředí. Chybně stanovené vstupní předpoklady mohou znamenat také neúspěšný či obtížně realizovatelný projekt. Vysoký význam nám tedy ukazuje na nutnost nepodcenit př́pravu technicko-ekonomických studií, které jsou součástí př́ípravného předinvestičního procesu. Cílem předinvestičních studií je především snížit rizika spojená s realizací projektu. Tyto studie jsou také nástrojem pro stanovení cílů projektu a možností pro jejich dosažení. 
Existující př́ležitosti a hodnocení podmínek v daném sektoru, či na daném území, nám pomáhá identifikovat studie př́ležitostí. Určitým mezistupněm mezi studií př́íležitostí a studií proveditelnosti je tzv. předběžná studie proveditelnosti, která je charakteristická nižší úrovní rozpracovanosti a menší hloubkou uskutečněné analýzy, než u studie proveditelnosti. Předběžná neboli úvodní studie proveditelnosti může být u malých a jednoduchých projektů dostatečným podkladem pro rozhodování, zda pokračovat realizací projektu. U náročných projektů slouží jako méně nákladná varianta pro rozhodnutí, zda v př́pravné fázi projektu pokračovat a dopracovat studii proveditelnosti. V předinvestičním procesu dále následuje zpracování studie proveditelnosti, jejímž smyslem je poskytnout veškeré podklady o projektové variantě či variantách důležitých pro investiční rozhodnutí. Výsledkem studie proveditelnosti je definování realizovatelnosti či nerealizovatelnosti projektu a jeho postoupení do další fáze života projektového cyklu.

Kritériem pro rozhodování o uskutečnění veřejných investičních akcí by měla být tzv. prospěšnost širokému spektru beneficientů. Nehodnotí se zde tedy pouze finanční výhodnost pro investora. Veřejný projekt je přijatelný, pokud přináší finančně udržitelné výstupy s dostatečným veřejným prospěchem. U veřejných projektů je tedy potřeba zkoumat, jak velký užitek resp. celospolečenský př́nos mají. Např. oprava staré budovy je užitečná a záslužná činnost, ale jelikož každá obec vlastní několik takovýchto budov či cest, veřejných prostranství apod., je nutné ocenit dopady projektu na ostatní subjekty a společnost jako celek tak, aby v soutěži projektů zvítězily projekty s nejvyšším celospolečenským či regionálním pozitivním dopadem. Tento př́stup napomůže účelnému vynakládání finančních prostředků.

V celém průběhu předinvestiční fáze projektu se můžeme také setkat $s$ tzv. podpůrnými studiemi. Tyto studie upřesňují nebo zkoumají různé aspekty související $s$ technickým řešením projekto či zjištováním dopadů a vlivů projektu. Součástí předinvestičního procesu také bývá zpracování hodnotící zprávy, která bývá často základním podkladem pro hodnocení projektu investičními a finančními institucemi, které by se mohly podílet na jeho financování. Nejedná se tedy o zpracování nových informací, ale sestavení skóre projektu na základě zjištěných skutečností v předchozích studiích. Hodnocení projektu prostřednictvím přiděleného skóre umožňuje následně subjektům rozhodnout např́iklad o přidělení úvěru apod.

\section{Literatura}

[1] FIALA, P. Projektové řizení -modely, metody, analýzy. Praha: Professional publishing, 2004. ISBN 80-80419-24-X.

[2] FOTR, SOUČEK. Podnikatelský záměr a investiční rozhodování. 2005.

[3] FROHLICH, HAWRANEK. Manual for Small Industiral Businesses: Project Design and Appraisal. Vídeň: UNIDO, 1994. ISBN 92-1-106295-0.

[4] Je analýza nákladi̊ a prínosů vhodným nástrojem pro hodnocení veřejných investic?

[5] MÁČE, M. Finanční analýza investičnich projektů - praktické príklady a použití. Hlavlíčkův Brod: Grada Publishing a. s., 2006. ISBN 80-247-1557-0.

[6] NĚMEC, V. Projektový management. Praha: Grada Publishing, 2006. ISBN 80-247-0392-0.

[7] OCHRANA, F. Veřejný sektora efektivní rozhodování. Praha: Management press, 2001. ISBN 80-7261-018-X.

[8] REILLY, F.,K., NORTON, E. A. Investments. 7. vyd., Mason, OH: Tomson Highter Education, 2007. ISBN 1-800-423-0563.

[9] SIEBER, P. Analýza nákladi̊ a přinosů, metodická přiručka. verze 1.4. Praha: Ministerstvo pro místní rozvoj, 2004.

[10] SIEBER, P. Studie proveditelnosti. Praha: Ministerstvo pro místní rozvoj, 2004.

[11] VÁCLAVKOVÁ, R.. Ostrava: VŠB - Technická univerzita Ostrava, 2010. In MEKON 2010: CD of participants' reviewed papers from 12th International Conference. str. 1-9. ISBN 978-80-2482165-8.

[12] WYSOCKI, R. K., Mc CARY. Effective Project Management. Third Edition. Indiana Polis: Wiley Publishing, 2003. str. 464. ISBN 978-0-471-43221-0. 